\title{
Review of the Relationship between Board Attributes and Firm Performance
}

\author{
Mohammed Mahmud Kakanda \\ Tunku Puteri Intan Safinaz - School of Accountancy \\ Universiti Utara Malaysia, Sintok, Kedah, Darul-Aman \\ Tel: 60-11-3393-8302 E-mail:manga4m@gmail.com
}

Basariah Salim

Tunku Puteri Intan Safinaz - School of Accountancy

Universiti Utara Malaysia, Sintok, Kedah, Darul-Aman

Tel: 60-19-470-0474 E-mail: basa1189@uum.edu.my

Sitraselvi Chandren

Tunku Puteri Intan Safinaz - School of Accountancy

Universiti Utara Malaysia, Sintok, Kedah, Darul-Aman

Tel: 60-4-928-7328Ｅ-mail: sitraselvi@uum.edu.my

Received: March 1, 2016 Accepted: April 30, $2016 \quad$ Published: June 1, 2016

doi:10.5296/ajfa.v8i1.9319 URL: http://dx.doi.org/10.5296/ajfa.v8i1.9319

\begin{abstract}
Corporate governance over the years has become an issue of global concern due to the 2008 economic crisis and several financial scandals and corporate failures. This has drawn the attention of policy makers, researchers, investors and regulatory institutions. Moreover, the most significant mechanism of corporate governance is board of directors. Therefore, the purpose of this paper is to review previous studies that examine the relationship between board attributes and firm performance, and to identify possible literature gaps. For the purpose of this review, related materials were being gathered from Emerald management e-Journals and Research Gate database. The paper synthesizes empirical findings on the relationship between selected dimensions of board attributes and firm performance. The




\section{Macrothink}

Asian Journal of Finance \& Accounting ISSN 1946-052X

paper identifies shortcoming of past studies and concluded by offering some avenues for future researches in this promising area of empirical research.

Keywords: Corporate governance, board attributes, firm performance, board size, board composition, board meeting 


\section{Introduction}

Can board of directors attributes influence firm's financial performance? A justifiable response to this question is through scanning the results of previous empirical studies on the subject matter. However, corporate governance over the years has become an issue of global concern due to the 2008 economic crisis and several financial scandals and corporate failures (e.g., Enron, WorldCom, Lehman Brothers, Parmalat e.t.c) (Jones, Li \& Cannella, Jr, 2015; Shahwan, 2014; Fallatah \& Dickins, 2012; Benjamin, 2009; Dalton, Hitt, Certo \& Dalton, 2007; Kyereboah-Coleman, 2007). Therefore, this has drawn the attention of policy makers, researchers, investors and regulatory institutions.

The attention increase in research on corporate governance was committed to members of corporate boards' influence on relevant organizational outcomes (Carpenter \& Westphal, 2001). Members of board of directors in both public and private companies are vested with large number of responsibilities. These responsibilities include an ethical duty to represent the interests of funds providers (investors/shareholders) and to monitor the financial stability and performance of the organization (Ethics Resource Center, 2002).

In past decades, "boards' influence on firm performance has normally been analyzed using variables linked to their formal composition and structure, but such analyses have usually failed to identify any substantive relationship between these factors and firm performance" (Dalton \& Dalton, 2011). Moreover, the relationship between boards of directors' attributes and firm performance is conundrum, as it remains unresolved in the academic literature (Rebeiz, 2015). Owing to this, empirical researches on the subject matter have been inconclusive and fragmented as accounted by Ontological, Methodological and Behavioural complexities.

Concisely, Rebeiz (2015) opined that 'Ontological complexities' barricaded researchers' consensus on boards' attributes and firm performance due to the complexity of an organization's legal, economic and social systems which plays an inter-influence role between the organization and the external environment. To 'Methodological complexities', positivists uses market or accounting indices in determining firm performance, where by both metrics suffer from measurement setbacks. The accounting metrics are based on historical values from financial statements, while market metrics are based on future expectations influenced by forces of demand and supply in the market. Whereas, 'Behavioural complexities' is on the basis that directors' independence is being influenced by existing culture in the board room and information control by the Chief Executive Officer (CEO) which hinders independent judgement by board members (Rebeiz, 2005; Aram \& Cowen 1983).

Previous studies on the relationship between boards' attributes and firm performance have measured performance as either using accounting based performance measures like return on assets (ROA), return on equity (ROE), net profit margin (NPM), dividend per share (DPS), and earnings per share (EPS) (e.g., Amba, 2013; Latif et al., 2013; Marn \& Romuald, 2012; Yasser, Entebang \& Mansor, 2011; Vance, 1978). In addition, market-based measures like Tobin's Q (e.g., Kyereboah-Coleman, 2007; Nicholson \& Kiel, 2003; Vafeas, 1999). While 
board of directors attributes is measured using different constructs like; board composition, board characteristics, board process, and board structure that are based on agency theory model (Zahra \& Pearce II, 1989).

Hence, this study aimed at reviewing the findings of previous studies that examined the relationship between corporate board of directors' attributes and firm performance, and to identify possible gaps in literature. The paper is divided into four sections. The first part is the introduction, which gives an in-look of the contents, then followed by materials/methods used. The third section provides the review of related literatures on some board attribute mechanisms and firm performance, while the last section is conclusion.

To achieve a comprehensive view of how boards' attributes relates to firms' financial performance, a broadly search was initiated within the academic literature in accounting and finance; and business management and strategy obtained from Emerald Management e-Journals and Research Gate database. However, the review was not base on time-period, but based on the keywords used for the title. In addition, not only those articles that involve empirical examination of how boards' attributes relates or impacts on financial performance in review of related literature is considered.

\section{Board of Directors' Attributes}

Corporate board of directors play numerous and integral roles in organizations. They are mainly saddle with the responsibility of (1) providing of oversight, advice, and counsel to Chief Executive Officers (CEOs), and (2) monitoring and if necessary disciplining CEOs (Finkelstein \& Mooney, 2003). Based on agency theory, executives (agents) possess significant freedoms and powers to manage shareholders (principals') resources. It is believing that the executives have some objectives that may be conflicting with that of the owners (principals), hence, ignoring shareholders' wealth maximization objective (Masson, 1971). In this regard, it is being expected that board of directors are to perform painstaking function of monitoring and rewarding top executives to ensure the attainment of shareholders' wealth maximization (Zahra \& Pearce II, 1989). Consequently, for board of directors to perform their functions effectively, some attributes must be in place.

However, boards of directors attributes are also referring to as board mechanisms. The classification of boards is under four different theoretical perspectives: (1) legalistic perspective, (2) Class Hegemony, (3) Resource dependence, and (4) Agency theory (Zahra \& Pearce II, 1989). In this review, board attributes have been approached based on agency theory as explained earlier. Board attributes under the agency theory includes board composition, board characteristics, board process and board structure. The explanations to these are comprehensively in the subsequent paragraphs.

Board composition connotes the number and mixture of different director types, for instance, executive and non-executive directors, independent and non-independent directors. To Zahra and Pearce II (1989), board composition involves both the size (number of directors that serve on the board) and director types (widely recognized dichotomy between inside and outside directors). However, some stream of researchers (e.g., Tauringana, 2015; Marn \& 
Romuald, 2012; Barisua, Tobira \& Lenee, 2012; Yasser, Entebang \& Abu Mansur, 2011), refer to board composition as the number of non-executive directors on the board of a company. In essence, this review has treated board size and board composition as separate and independent attributes.

On the other hand, Board Characteristics denotes the distinguishing features of persons serving on a board. These features are directors' background (age, level of education and expertise) and personality (Hambrick, 1987, Mueller, 1981). Board structure as asserted by Zahra and Pearce II (1989) refers to the dimensions or specifications of the board's organization that include: (1) number and type of committees, (2) committee membership and leadership, and (3) flow of information among the committees. Whereas Board process involve the series of approaches taken by the board in making decisions. It includes dimensions like; frequency and number of meetings, formality of board proceedings, self-evaluation of board, CEO-board relation and level of agreement among directors on prevailing issues (Mueller, 1979).

Consequently, this review is not restricted to the constructs of board attributes in totality, but to selected dimensions of the attributes like board size, board composition and board meetings. The review of theses dimensions is in relation to firm performance under independent headings.

\section{Firm Performance}

Corporate performance is an essential requirement for an organization's survival and growth(Kakanda, Bello, \& Abba, 2016). Corporate performance relates to the process by which limited resources at organization's disposal are utilize effectively and efficiently in attaining the general objective of the enterprise for both present and future opportunities (Marn \& Romuald, 2012; Yasser, Entebang \& Abu Mansor, 2011). However, Berger \& Patti (2002) are of the view that "A firm's financial performance, in the view of the shareholder is measured by how 'better off' the shareholder is at the end of a period, than he was at the beginning. Also, this can be determined using ratios derived from financial statements; mainly the balance sheet and income statement, or using data on stock market prices". Here, 'better off' means the increase in value of shareholders from the beginning to the end of a given accounting period (Kakanda, et al., 2016).

Coherently, since agency theory argues that agency relationships should be the most stressing point when studying and analyzing corporate governance. Therefore, it is assuming that contribution of board of directors to organizational performance occurs by reducing agency cost arising from non-consensus of interest between the executives and the established organizational goals and procedures (Mizruchi, 1983). In essence, it is of the expectation that boards will enhance the financial performance of their organizations by maximizing shareholders' wealth.

\subsection{Board size and Firm performance:}

Board size is the magnitude of board of directors of a company. It is the total number of directors serving on the board of a company (Ogege \& Boloupremo, 2014; Vafeas, 1999). 
However, board size is view as the most crucial dimension of board attributes. This is because there are conflicting views in literature regarding board size. To the proponents of agency theory, it is assuming that a smaller board size is adequate and effective, because it has minimised monitoring duties, which encourage efficiency, coordination and communication. While an increase in board size causes delay in decision-making, coordination and communication; creates more conflict of interest (between executives and owners) and demoralized majority of members, hence affecting firm performance (Abdurrouf, 2011; Nanka-Bruce, 2011; Yermack, 1996; Jensen, 1993).

Conversely, it was also argued that as board size increases, the position of the directors are improved which gives them more right to exercise their power in governing the organization, as the CEO dominance on the board is reduced and become more difficult (Zahra \& Pearce II, 1989). Therefore, this leads to a positive relation between board size and firm performance.

Moreover, Lipton and Lorsch (1992) reported that number of board members of a company should be between seven and eight. This assertion is also consistent with the opinion of Jensen (1993). In this effect, boards that have eight or less members stand a chance to maintain better focus, participation, good interaction and meaningful debate (Firsteberg \& Malkiel, 1994). However, a required number of board members depend on industry-specific and size of firms; for instance, banking industry is found to have board size that is larger than that of manufacturing industry (Adams \& Mehran, 2003).

Subsequently, some studies report that larger boards are assume to have directors with heterogeneous educational and industrial background and skill that will help to enhance actions of the firm, hence, improving performance (Pfeffer, 1987; Herman, 1981; Bacon, 1973). Gill and Obradovich (2012) whose study aimed at examining the impact of corporate governance and financial-leverage on the value of American firms, found that larger board size larger board size negatively affects the value of American firms. Other stream of studies that found negative relationship between board size and firm performance include Ali and Nasir (2014), Ibrahim and Abdul Samed (2011), Lin (2011), Juras and Hinson (2008), and Yawson (2006) among others.

On the other hand, Yasser et al. (2011) found a significant positive relationship between board size and performance measured by return on equity (ROE) and profit margin (PM). Concurrently, Al-Matari, Al-Swidi and Faudziah (2014) found board size to be positively but insignificantly related to financial performance (measured by ROA) of listed Muscat Security Market (MSM) in Oman. In the same vein, the finding of Marn and Romuald (2012) indicates that board size has significant effect on performance of listed Malaysian firm. Earnings per share (EPS) measure the performance here. Moreover, larger board size is being found to improve the monitoring role as well enhances economic performance (Maharaj, 2008; Joh, 2003). Based on the above review, the first hypothesis in this review is develope as:

\section{$H_{1}$ : Board size has positive relationship with firm performance}




\subsection{Board composition and Firm performance:}

Board composition is the number of non-executive directors on board of a company. It is the ratio of non-executive directors to total directors (Barisua et al., 2012; Marn \& Romuald, 2012; Yasser et al., 2011). It has been presumed that boards with significant outside directors will effectively perform their duty and have better decisions than board that is dominated by inside directors. Fama and Jensen (1983), Spencer (1983), and Jones and Goldberg (1982), argued that non-executive directors' representation on the board increases: board independence, directors' objectivity and enhances directors' expertise. On the contrary, other studies suggested that non-executive directors do not have the required time, knowledge, skill and expertise to carry out their work effectively (Geneen, 1984; Vance, 1983).

However, some group of empirical studies has found that increasing number of outside directors will influence performance. For instance, Barisua et al. (2012) has found that board of directors' composition is positive and significantly related to performance (EPS) of publicly traded Deposit Money Banks in Nigeria. Connelly and Limpaphayom (2004) found that board composition has positive relation with profitability of life insurance firms in Thailand (Connelly \& Limpaphayom, 2004). Other studies that belong to this group are Abdurrouf (2011), Nanka-Bruce (2011), Saibaba and Ansari, (2011), Bhagat and Bolton (2009), Juras and Hinson (2008) among others.

In contrast, other studies found a negative relationship between board composition and firm performance. For example, Marn and Romuald (2012) found that board composition has no significant positive effect on the performance (EPS) of Malaysian listed firms. In addition, the study by Barisua et al. (2012) has found board composition to be negative and significantly related to performance (net profit margin) of Deposit Money Banks in Nigeria. The likes of these studies are Bhagat and Bolton (2008), Bozec (2005), Connelly and Limpaphayom (2004), Agrawal and Knoeber (1996), and Yermack (1996). Despite the conflicting findings on board composition and firm performance, yet this review hypothesized:

\section{$\mathrm{H}_{2}$ : Board composition has positive relationship with firm performance}

\subsection{Board meeting and Firm performance:}

Board meeting refers to the gathering of directors on the board to discuss issues regarding the company. It is measured as the number of meetings during a year by a company board of directors (Al-Matari et al., 2014; Chechet, Yancy Jnr \& Akanet, 2013; Vafeas, 1999). Board meetings play a significant role to the success of a company. In addition, board meetings serve as an important avenue for effective decision making of a company. Board of directors hold meetings on behalf of the company to discuss issues of the past, present and future that is related to the company, and resolutions passed during board meetings. Therefore, the more the number of board meetings, the better for a company, because the boards will have more and better chances of making various decisions (Khan \& Javid, 2011; Pearce \& Zahra, 1992).

However, Vafeas (1999) whose study aimed at examining the relationship between board meeting frequency and firm performance found that Boards that meet more frequently are 
valued less by the market, a finding that seems to be determined by share price declines followed by higher meeting frequencies. Whereas Mangena and Pike (2005) found that, there is a significant positive relationship between the frequency of board meetings and performance of companies listed on the floor of Zimbabwe stock exchange. Again, there is a positive relationship between the disclosures of the frequency of board meetings and firm performance (Brown \& Caylor, 2004). In this effect, attending board meetings by members ought to produce important resources to directors in enhancing the adequacy of the board (Said, Omar, \& Abdullah, 2012).

Additionally, some empirical studies that found boards meeting to be positively related to performance are but not limited to Liang, Xu and Jiraporn (2013), Gavrea and Stegerean (2012), Kang and Kim (2011) and Khan and Javid (2011), Brown and Caylor (2004). Equally important, Jensen (1993) opines that: "daily tasks those continue most of the board's meeting time and hence this limits the chances for external directors to conduct a meaningful oversight over management". Jensen further stressed that board should not be over active as activity of board represents a reaction to adverse performance. In regards to this, some empirical studies that found a negative relationship between board meeting and performance are; Danoshana and Ravivathani (2014), Garcia-Sanchez (2010), and Kamardin (2009) among others. Therefore, this review hypothesized that:

\section{H3: Board meeting has positive relationship with firm performance}

\section{Conclusion}

The aim of this study was to review previous studies on board of directors' attributes and firm performance and to identify possible literature gaps. The review is based on causal-effect relationship between board dimensions such as board size, board composition and board meeting and firm financial performance. Albeit, there are stream of studies on board attributes and firm performance, yet the results are still conflicting which make research in the area to be inconclusive. Nevertheless, this does not render the findings of previous studies invalid.

More importantly, the existing research studies have reflected limitations that accentuate the problem that is associated with the following:

(1) In scanning the direct relationship between dimensions of boards attribute and firm performance, the relationship might be influence indirectly by other factors like social, economic and political that might be the strength, weakness, opportunities, and threats (SWOT) posed by the market within which the business operates. The relationship can also be influence by the different roles played by boards to arrive at strategic outcomes which later influence performance (Zahra \& Pearce II, 1989). This is an avenue for future researchers to use mediations or moderations in examining relationship between board attributes and firm performance.

(2) Methodological complexities and the use of historic data is another limitation in studies of board attribute and firm performance (Rebeiz, 2015). This problem can be lessening through integrating deductive analysis with interpretive reasoning. This will help future researchers to 
have more result that is reliable since analyses from both secondary and primary data source will be complementing each other in result interpretations. Hence, improve research findings from data analyses with more accuracy and precision.

(3) The use of archival data from different sectors on a stock exchange can also affect the outcome of a study. Different sectors are characterized by different industry standard, different accounting policies, size and periods of operation. Future researchers can use companies with homogenous characteristics or make comparative analysis between firms from available sectors. In addition, conflicting results from studies in different countries might be due to economic and political differences among nations.

\section{Acknowledgement}

The research is financed by Othman Yeop Abdullah (OYA) GraduateSchool of Business, University Utara Malaysia (UUM) Sintok. Thanks to Associate Professor Ahmed Bawa Bello and Dr. Mohammed Abba, Modibbo Adama University of Technology, Yola.

\section{References}

Abdurrouf, M. A. (2011). The relationship between corporate governance and value of the firm in developing countries: Evidence from Bangladesh. The InternationalJournal of Applied Economics and Finance, 5(3), 237-244. http://dx.doi.org/10.3923/ijaef.2011.237.244

Adams, R., \& Mehran, H. (2003). Is Corporate Governance Different for Bank Holding Companies? Economic Policy Review, 9, 123-142. http://dx.doi.org/10.2139/ssrn.387561

Agrawal, A., \& Knoeber, C. (1996). Firm performance and mechanisms to control Agency problems between managers and shareholders. Journal of Financial Quantitative Analysis, 31(3), 377-39. http://dx.doi.org/10.2307/2331397

Ali, A., \& Nasir, S. Bin. (2014). Impact of board characteristics and audit committee on financial performance: A Study of Manufacturing Sector of Pakistan, ResearchJournal of Finance and Accounting, 5(7), 144-1 52

Al-Matari, E. M., Al-Swidi, A. K., \& Faudziah, H. Bt.F. (2014). The Effect of the Relationship between Board of Directors Characteristics on Firm Performance in Oman: Empirical Study. Middle-East Journal of Scientific Research, 21(3), 556-574. DOI: 10.5829/idosi.mejsr.2014.21.03.21410

Amba, M. S. (2013). Does CEO Duality Enhance Firms Business Performance? Empirical Evidence from Bahrain, International Journal of Business and Social Science,4(6), 88-91

Aram, J. D., \& Cowen, S. S. (1983). Information for corporate directors: The role of the board in the management process. New York: National Association of Accountants

Bacon, J. (1973). Corporate directorship practices: The audit committees of board. New York: The Conference Board 
Barisua, N., Torbira, F., \& Lenee, L. (2012). Corporate Governance and Financial Performance of Publicly Listed Deposit Money Banks in Nigeria Reiko International Journal of Social and Economic Research (Rijser) 4(4)

Benjamin, I. E. (2009). Corporate governance structure and firm performance in developing economies: evidence from Nigeria. Corporate Governance: The international journal of business in society, 9(3), 231-243. http://dx.doi.org/10.1108/14720700910964307

Berger, A. N., \& Patti, E. B. D. (2002). Capital Structure and Firm Performance: A new Approach to testing agency theory and an Application to the banking Industry (Finance and Economics Discussion Series 2002-54). USA: Board of Governors of the Federal Reserve System, RePEC: $\quad$ Fip:Fedgfe. [Online] Available: http://www.federalreserve.gov/Pubs/Feds/2002/200254/200254pap.pdf (September 20, 2015)

Bhagat, S., \& Bolton, B. (2008). Corporate governance and fm performance. Journal of Corporate Finance, 14, 257-273. http://dx.doi.org/10.1016/j.jcorpfin.2008.03.006

Bhagat, S., \& Bolton, B. (2009). Corporate governance and financial performance: Recent Evidence Sanjai Bhagat, 1-57.

Bozec, R. (2005). Board of Directors, Market Discipline and Firm Performance. Journal of business Finance and Accounting, 32(9) \& (10), 1921-1960. http://dx.doi.org/10.1111/j.0306-686X.2005.00652.x

Brown, L. D., \& Caylor, M. L. (2004). Corporate Governance and Firm Performance, [Online] Availablehttp://papers,ssrn.com/sol3/papers.cfm?abstract_id=586423. (September 20, 2015)

Chechet, L. I., Yancy Jnr, F. S., \& Akanet, S. (2013). Impact of Internal Governance Mechanisms on Corporate Performance in Deposit Money Banks in Nigeria. International Journal of Arts and Commerce, 2(8), 35-46

Connelly, J. T., \& Limpaphayom, P. (2004). Environmental reporting and firm performance: evidence from Thailand. The Journal of Corporate Citizenship, 13(1), 37-149

Dalton, D. R., Hitt, M. A., Certo, S. T., \& Dalton, C. M. (2007). The fundamental agency problem and its mitigation: Independence, equity, and the market for corporate control. Annals of the Academy of Management, 1, 1-64. http://dx.doi.org/10.1080/078559806

Dalton, D. R., \& Dalton, C. M. (2011). Integration of Micro and Macro Studies in Governance Research: CEO Duality, Board Composition and Financial Performance, Journal of Management, 37, 404-411. http://dx.doi.org/10.1177/0149206310373399

Danoshana, S., \& Ravivathani, T. (2014). Impact of corporate governance framework on the organizational performance. A study on financial institutions in Sri Lanka. International Journal of Technological Exploration and Learning, 16(1), 73-78

Ethics Resource Center (2002). Developing a Code of Conduct for a Corporate Board of Directors: 
Availablewww.ethics.org/resource/developing-code-conduct-corporate-board-directors-road map (September 13, 2015)

Fallatah, Y. \& Dickins, D. (2012). Corporate governance and firm performance and value in Saudi Arabia. African Journal of Business Management, 6(36), 10025-10034. http://dx.doi.org/10.5897/AJBM12.008

Fama, E., \& Jensen, M. (1983). Separation of Ownership and Control. Journal of Law and Economics, 26, 301-325. http://dx.doi.org/10.1086/467037

Finkelstein, S., \& Mooney, C. A. (2003). Not the usual suspects: How to use board process to make boards better. Academy of Management Executive, 17(2), 101-113. http://dx.doi.org/10.5465/AME.2003.10025204

Firstenberg, P. B., \& Malkiel, B.G. (1994). The twenty-first century boardroom: Who will be in charge, Sloan Management Review, 36, 27-35

Garcia-Sanchez, I. M. (2010). The effectiveness of corporate governance: Board structure and business technical efficiency in Spain. CEJOR, 18, 31 1-339.

Gavrea. C., \& Stegerean. R. (2012). Corporate governance and firm performance: The Romanian case. Managerial Challenges of the Contemporary Society, 3(1), 179-1 85

Geneen, H. (1984). Managing. New York: Doubleday

Gill, A., \& Obradovich, J. D. (2012). The Impact of Corporate Governance and Financial Leverage on the Value of American Firms. International Research Journal of Finance and Economics,91, 1-14

Hambrick, D. C. (1987). The top management team: Key to strategic success. California Management Review, 30, 88-108. http://dx.doi.org/10.2307/41165268

Herman, E. S. (1981). Corporate control, corporate power. Cambridge, UK: Cambridge University Press

Ibrahim, H., \& Abdul Samed, F. A. (2011). Agency costs, corporate governance mechanisms and performance of public listed family firms in Malaysia. South African Journal of Business Management, 42(3), 17-26

Jensen, M.C. (1993). The Modern Industrial Revolution, Exit, and the Failure of Internal Control Systems. Journal of Finance, 48(3), 831-880. http://dx.doi.org/10.1111/j.1540-6261.1993.tb04022.x

Joh, S. W. (2003). Corporate governance and firm profitability: evidence from Korea before the economic crisis. Journal of Financial Economics, 68,287-322. http://dx.doi.org/10.1016/S0304-405X(03)00068-0

Jones, D. C., Li. M., \& Cannella, Jr. A. A. (2015). Responses to a Governance Mandate: The Adoption of Governance Committees by NSE Firms. Journal of Management, 41(7), 1873-1897. http://dx.doi.org/10.1177/0149206313484515 
Jones, T. M., \& Goldberg, L. D. (1982). Governing the large Corporation: more arguments for public directors. Academy of Management Review, 7, 603-611. http://dx.doi.org/10.2307/257227

Juras, P. E., \& Hinson, Y. L. (2008). Examining the effect of board characteristics on agency costs and selected performance measures in banks. Academy of BankingStudies Journal, 7(2), $87-108$

Kakanda, M. M., Bello, A. B., \& Abba, M. (2016). Effect of Capital Structure on Performance of Listed Consumer Goods Companies in Nigeria. Research Journal of Finance and Accounting, 7(8), 211-219

Kamardin, H. (2009). The impact of corporate governance and board performance on the performance of public listed companies in Malaysia. Ph.D. Dissertation, Universiti Sains Malaysia.

Kang, S., \& Kirn, Y. (2011). Does earnings management arnplify the association between corporate governance and firm performance? Evidence from Korea. International Business and Economies Research Journal, 10(2), 53-47

Khan, M., \& Javid, A. (2011). Determinants of board effectiveness: Logit model ferheen kayani. Interdisciplinary Journal of Contemporary Research in Business, 3(2), 1970-1981

Kyereboah-Coleman, A. (2007). Corporate Governance and Firm Performance in Africa: A Dynamic Panel Data Analysis. A paper presented at the "International Conference on Corporate Governance in Emerging Markets" $15^{\text {th }}-17^{\text {th }}$ November, Sabanci University, Istanbul, Turkey.

Liang, C.-J., Lin, Y.-L., \& Huang, T.-T. (201 1). Does endogenously determined ownership matter on performance? Dynamic evidence from the emerging Taiwan market. Emerging Markets Finance and Trade, 47(6), 120-133.

Lin, C. (2011). An examination of board and firm performance: evidence from Taiwan. The International Journal of Business and Finance Research,5(4), 17-35

Lipton, M., \&. Lorch, J. W. (1992). A Modest Proposal for improved Corporate Governance. The Business Lawyer, 48(1), 59-77

Maharaj, R. (2008). Corporate governance decision-making model: How to nominate skilled board members, by addressing the formal and informal systems. International Journal of Disclosure and Governance, 6,106-126. http://dx.doi.org/10.1057/jdg.2008.27

Mangena, M. and Pike, R. (2005), The effect of audit committee shareholding, financial expertise and size on interim financial disclosures, Accounting andBusiness Research,35 (4), 327-349

Marn, J. T. K., \& Romuald .D.F. (2012). The Impact of Corporate Governance Mechanism and Corporate performance: A study of Listed Companies in Malaysia. Journal for the Advancement of Science \& Arts,3(1), 31-45 
Masson, R. T. (1971). Executive motivations, earnings and consequent equity performance. Journal of Political Economy, 79, 1278-1292. http://dx.doi.org/10.1086/259835

Mizruchi, M. S. (1983). Who control whom? An examination of the relation between management and board of directors in large American corporation. Academy of Management Review, 8(3), 426-435.

Mueller, R. K. (1979). Board compass. MA: D. C. Heath.

Mueller, R. K. (1981). The incomplete board: The unfolding of corporate governance. Lexington: Lexington Books.

Nanka-Bruce, D. (2011). Corporate governance mechanisms and firm efficiency. International Journal of Business and Management, 6(5), 28-41.

Nicholson, G. J., \& Kiel, G. C (2003). Board Composition and Corporate Performance: How the Australian Experience Informs Contrasting Theories of Corporate Governance, Corporate Governance: An International Review,11(3), 189-205

Ogege S., \& Boloupremo T. (2014). Corporate Governance and Financial Performance of Banks: Evidence from Nigeria, Hyperion Economic Journal Year II, 2(2), 25-36

Pfeffer, J. (1983). Organizational demography. In L. L. Cummings, \& B. M. Staw (Eds.), Research in organizational behaviour, 5, 299-357 Greenwich, CT: JAI Press

Rebeiz, K. (2005). The two dimension of corporate governance independence, Advances in Financial Economics, 11, 209-230. http://dx.doi.org/10.1016/S1569-3732(04)11009-8

Rebeiz, S. K. (2015). Boardroom's independence and corporate performance: the ever-elusive conundrum, Corporate Governance, 15(5), 747-758. http://dx.doi.org/10.1108/CG-07-2015-0096

Saibaba, M. D., \& Ansari, V. A. (2011). Audit Committees and Corporate Governance: A Study of Select Companies Listed in the Indian Bourses. The IUP Journal of Accounting Research \& Audit Practices, 10(3), 46-54

Said, R., Omar, N., \& Abdullah, W. N. (2012). Empirical investigations on boards, business characteristics, human capital and environmental reporting. Social Responsibility Journal, 9, 534-553. http://dx.doi.org/10.1108/SRJ-02-2012-0019

Shahwan, T. M. (2015). The effects of Corporate Governance on Financial Performance and Financial Distress: Evidence from Egypt, Corporate Governance, 15(5), 641-662 http://dx.doi.org/10.1108/CG-11-2014-0140

Spencer, A. (1983). On the edge of the organization: The role of outside director. New York: Wiley

Tauringana, G. A. A. V. (2015). Corporate Governance and Performance of UK Listed Small and Medium Enterprises. The International Journal of Business in Society, 15(5), 1-26 http://dx.doi.org/10.1108/CG-03-2015-0029 
Vance, S. C. (1978). Assessing corporate performance by boardroom attributes. Journal of Business Research, 6, 203-220. http://dx.doi.org/10.1016/0148-2963(78)90024-3

Vance, S. C. (1983). Corporate leadership: Boards, directors, and strategy. New York: McGraw-Hill.

Vafeas, N. (1999). Board meeting frequency and firm Performance, Journal of Financial Economics, 53, 113-142. http://dx.doi.org/10.1016/S0304-405X(99)00018-5

Yasser, Q. R., Entebang, H., \& Abu Mansor, S. A. (2011). Corporate Governance and Firm Performance in Pakistan: The case of Karachi Stock Exchange (KSE)-30, Journal of Economics and International Finance, 3(8), 482-491.

Yawson, A. (2006). Evaluating the characteristics of corporate boards associated with layoff decisions. Corporate $\quad$ Governance, $\quad$ 14(2), http://dx.doi.org/10.1111/j.1467-8683.2006.00488.x

Yermack, D. (1996). Higher market valuation of companies with a small board of directors. Journal of Financial Economics, 40(2), 185-211. http://dx.doi.org/10.1016/0304-405X(95)00844-5

Zahra, A. S., \& Pearce II, A. J. (1989). Boards of Directors and Corporate Financial Performance: A Review and Integrative Model, Journal of Management, 15(2), 291-334. http://dx.doi.org/10.1177/014920638901500208 